\title{
Pre- and postoperative respiratory muscle strength, body mass index and fasting glucose profile of patients with type 2 diabetes mellitus submitted to metabolic surgery
}

\author{
Perfil de pacientes com diabetes mellitus tipo 2 quanto a força \\ muscular respiratória, o índice de massa corpórea e a glicemia em \\ jejum avaliados no pré e no pós-operatório de cirurgia metabólica
}

\author{
Ariana de Melo Tosta $\left(\mathbb{D}\right.$, Marisa de Carvalho Borges ${ }^{(D)}$, Élida Mara Carneiro da Silva $\mathbb{D}^{(D)}$ \\ Alex Augusto da Silva (D), Eduardo Crema ${ }^{(1) *}$
}

Universidade Federal do Triângulo Mineiro (UFTM), Uberaba MG, Brazil

\begin{abstract}
Introduction: The lung is considered a target organ in diabetes mellitus as a consequence of alterations secondary to chronic hyperglycemia that compromise respiratory muscle strength. Metabolic surgery for improving diabetes mellitus has beneficial effects on weight loss and glucose metabolism. Objective: The objective of this study was to evaluate the respiratory muscle strength, assessed by MIP and MEP, body mass index (BMI) and fasting glucose profile of patients with type 2 diabetes mellitus before and after metabolic surgery without gastric resection. Method: Seventeen patients with type 2 diabetes mellitus participated in the study. The participants had a mean age of $44.8 \pm 11.81$ years. Results: The results showed a significant decrease of MEP values in the immediate postoperative period when compared to the preoperative period ( $\mathrm{p}=0.001)$, while no significant results were obtained for MIP. Regarding BMI and fasting glucose, significant weight loss and a significant reduction in fasting
\end{abstract}

\footnotetext{
*AMT: MS, e-mail: arianatosta@hotmail.com MCB: PhD, e-mail: marisaborges.uftm@gmail.com EMCS: PhD, e-mail: elidamc16@gmail.com AAS: PhD, e-mail: alexuftm@yahoo.com.br EC: PhD, e-mail: cremauftm@mednet.com.br
} 
glucose levels were observed in the late postoperative period ( $\mathrm{p}=0.006$ and $\mathrm{p}=0.007$, respectively). Conclusion: The MIP and MEP were reestablished and satisfactory results were obtained for BMI and fasting glucose in the late postoperative period. Further studies are needed to monitor patients in the pre- and postoperative period of metabolic surgery, identifying complications and acting on the care and recovery of these patients.

Keywords: Diabetes Mellitus. Surgery. Respiratory Muscle Strength. Body Mass Index. Blood Glucose.

Resumo

Introdução: $O$ pulmão é considerado um dos órgãos-alvo do diabetes mellitus, como consequência das alterações secundárias à hiperglicemia crônica, comprometendo a força muscular respiratória. A cirurgia metabólica para a meIhora do diabetes mellitus exerce efeitos benéficos na perda de peso e no metabolismo da glicose. Objetivo: O objetivo deste estudo foi avaliar o perfil da força muscular respiratória, avaliada por PImáx e PEmáx, o índice de massa corporal (IMC) e a glicemia em jejum de pacientes com diabetes mellitus tipo 2 antes e após a cirurgia metabólica sem resseç̧ão gástrica. Método: Dezessete pacientes com diabetes mellitus tipo 2 participaram do estudo. Os participantes tinham idade média de 44,8ะ11,81 anos. Resultados: Os resultados mostraram uma diminuição significativa dos valores da PEmáx no pós-operatório imediato, quando comparado ao pré-operatório $(p=0,001)$, enquanto não foram obtidos resultados significativos para a PImáx. Em relação ao IMC è glicemia em jejum, observou-se perda significativa de peso e redução significativa dos níveis de glicemia de jejum no pós-operatório tardio ( $p=0,006 ; p=0,007$, respectivamente). Conclusão: A PImáx e a PEmáx foram restabelecidas e resultados satisfatórios foram obtidos para IMC e glicemia de jejum no pós-operatório tardio. Mais estudos são necessários para monitorar pacientes no pré e pós-operatório de cirurgia metabólica, identificando complicações e atuando no cuidado e recuperação desses pacientes.

Palavras-chave: Diabetes Mellitus. Cirurgia. Força Muscular Respiratória. Índice de Massa Corporal. Glicemia em Jejum.

\section{Introduction}

Diabetes mellitus is a syndrome of multiple etiology caused by the lack of insulin and/or the inability of insulin to adequately exert its effects, resulting in insulin resistance. The condition is characterized by the presence of chronic hyperglycemia, frequently accompanied by dyslipidemia, arterial hypertension and endothelial dysfunction. Diabetes is associated with increased mortality and a high risk of developing micro- and macrovascular complications, as well as neuropathies. The disease can result in blindness, renal failure and limb amputation, and is responsible for excessive healthcare expenditure and a substantial reduction in work capacity and life expectancy [1].

The lung has been recognized as a target organ in diabetes mellitus as a consequence of alterations secondary to chronic hyperglycemia. The pulmonary complications in diabetes mellitus include a reduction in lung volumes, a decline in carbon monoxide diffusing capacity, decreased elastic lung recoil, and reduced inspiratory muscle strength [2].
The currently estimated prevalence of diabetes in the world population is 387 million and this number is expected to reach 471 million in 2035. The number of diabetic people is increasing as a result of the growth and aging of the population, increased urbanization, progressively increasing prevalence of obesity and sedentary behavior, and the greater survival of patients with diabetes mellitus [3]. Metabolic surgery for the improvement of diabetes mellitus consists of ileal interposition with removal of a segment of the distal ileum and its insertion into the proximal small intestine, a procedure that promotes early satiety and exerts beneficial effects on glucose metabolism and weight loss $[4,5]$. However, respiratory problems are directly associated with a reduction of respiratory muscle strength, which occurs in the postoperative period of abdominal surgeries [6].

The objective of the present study was to evaluate the respiratory muscle strength, assessed by maximal inspiratory pressure (MIP) and maximal expiratory pressure (MEP), body mass index (BMI) and fasting glucose 
profile of patients with type 2 diabetes mellitus before and after metabolic surgery without gastric resection.

\section{Method}

A prospective study was performed by the Digestive Surgery Discipline at Hospital das Clínicas (Universidade Federal do Triângulo Mineiro - UFTM, Brazil). The data were collected between January 2011 and December 2013. After receiving detailed information about the objectives of the study, the data of each patient were recorded on an assessment chart and each patient provided free written informed consent. Twenty patients were initially selected and 17 patients participated in all assessments, including 10 (58.8\%) women and $7(41.2 \%)$ men aged between 30 and 65 years (44.8 \pm 11.81 years). The study was approved by the Ethics Committee of UFTM (Approval No. 1264/2016).

The criteria for inclusion were patients with type 2 diabetes mellitus and an indication for metabolic surgery, age older than 21 years, BMI between 23 and $35 \mathrm{~kg} /$ $\mathrm{m}^{2}$, capacity to understand the objective of the study and to undergo the pulmonary function tests, and providing written informed consent. Exclusion criteria were: severe heart disease, neurological or cognitive deficit impairing the pulmonary function tests, systemic diseases, respiratory infection and/or symptomatic allergic sinus disease, chronic obstructive pulmonary disease, a previous diagnosis of bronchial asthma, pleuropulmonary anomalies, chest deformities, a suspicion or confirmation of liver cirrhosis, coagulopathy (platelet count less than $50,000 / \mu \mathrm{l})$, dual antiplatelet therapy (acetylsalicylic acid and clopidogrel), acute and icteric pancreatitis, high surgical risk according to the American Society of Anesthesiology (ASA III and IV) (1963), and type 2 diabetes mellitus for more than 10 years.

All patients were submitted to duodenal-jejunal exclusion surgery with interposition of the ileal segment without gastric resection. The procedure consists of the interposition of an ileal segment of approximately 100 $\mathrm{cm}$, which is transposed and anastomosed to the duodenum at $2 \mathrm{~cm}$ from the pylorus and to the jejunum at $70 \mathrm{~cm}$ from the angle of Treitz, thus excluding $100 \mathrm{~cm}$ of the duodenal-jejunal segment.

MIP, MEP, BMI and fasting glucose were evaluated 24 hours before the surgical procedure (preoperative) and 24 hours (immediate postoperative, P01) and 2 years after the surgical procedure (late postoperative, $\mathrm{PO} 2$ ).
Evaluation of Respiratory Muscle Strength

Respiratory muscle strength was evaluated by measuring the MIP and MEP. This approach permits a simple, rapid and reproducible assessment of respiratory muscle strength.

MIP and MEP were measured with a manovacuometer (Comercial Médica; -300 to $300 \mathrm{cmH} 20$ ), with the patient sitting comfortably and using a nose clip and rigid mouthpiece. For the measurement of MIP, the patient was instructed to slowly exhale fully to residual volume so that a maximal inspiratory effort was performed with the orifice of the tube occluded. MEP was obtained when the patient inspired to her total lung capacity and then performed a maximal expiratory effort against the orifice of the occluded tube [7].

The MIP and MEP measurements were sustained for 2 seconds and performed three times, with a resting interval of 2 minutes each. There was an interval of 5 minutes between the MIP and MEP measurement. Only the highest value of the three measurements of MIP and MEP was considered for analysis.

In this study, the MIP and MEP values found were compared to those predicted with the equations of Neder et al. [8] described below:

\section{MIP}

Women: $y=110.4-0.49$ (age); standard error of the estimate $=9.1$.

Men: $y=155.3-0.80$ (age); standard error of the estimate $=17.3$.

PEMAX

Women: $y=115.6-0.61$ (age); standard error of the estimate $=11.2$.

Men: $y=165.3-0.81$ (age); standard error of the estimate $=15.6$.

\section{Body Mass Index}

Weight was measured with a Filizola digital electronic scale (capacity of $150 \mathrm{~kg}$ ) to the nearest $50 \mathrm{~g}$, with the subject barefoot and wearing minimal clothing. The weight of each participant was evaluated at the same pre-defined time. Height was measured with a millimeter vertical anthropometer $(2 \mathrm{~m}$ long and scale of 0.5 $\mathrm{cm})$. The patients were barefoot, standing erect with the feet forming an angle of approximately 450 , and looking 
directly ahead, with the back and posterior part of the knees touching the wall. The BMI was calculated by dividing the weight in kilograms by the height in meters squared $\left(\mathrm{kg} / \mathrm{m}^{2}\right)$, and was classified according to the World Health Organization classification [9]: healthy: $\mathrm{BMI} \geq 18.5$ and $<25 \mathrm{~kg} / \mathrm{m}^{2}$; overweight: $\mathrm{BMI} \geq 25$ and $<30 \mathrm{~kg} / \mathrm{m}^{2}$; obese: $\mathrm{BMI} \geq 30 \mathrm{~kg} / \mathrm{m}^{2}$.

\section{Fasting Glucose}

Blood samples were collected after a minimum fast of 8 hours. Venous blood samples were obtained by puncture of the basilic or median cubital vein with a disposable hypodermic syringe. About $3 \mathrm{ml}$ of blood was collected into a tube containing sodium fluoride to prevent glucose consumption and homogenized. The tube was centrifuged for 5 minutes at 2,500 rpm for the separation of plasma and the samples were stored at $4^{\circ} \mathrm{C}$. Glucose was determined in the plasma samples by a colorimetric enzymatic method with glucose oxidase (Biosystems, Barcelona, Spain) in a BTS 310 analyzer according to manufacturer specifications. The biochemistry laboratory of UFTM performed the glucose measurements in the plasma samples obtained from venous blood. Fasting glucose levels ranging from 70 to $110 \mathrm{mg} / \mathrm{dl}$ were classified as normal.

\section{Statistical Analysis}

The Kolmogorov-Smirnov test was used to verify whether the data were normally distributed. Parametric data were compared by the Student t-test and nonparametric data by the Wilcoxon test. Correlations were tested using Pearson's and Spearman's correlation coefficients. Differences were considered significant when $\mathrm{p}<0.05$. The Microsoft Excel 2010, GraphPad Prism 5.0 and SPSS 16.0 programs were used for statistical analysis.

\section{Results}

In the present study, 17 patients who underwent metabolic surgery were evaluated. The anthropometric variables and clinical and surgical data are presented in Table 1. None of the patients developed complications during the postoperative period until hospital discharge.

Table 1 - Anthropometric variables, clinical data referring to the first evaluation and surgical data of patients with diabetes mellitus undergoing metabolic surgery $(n=17)$

\begin{tabular}{lc}
\hline Variable & \\
Gender (n, \%) & $10(58.8 \%)$ \\
Female & $7(41.2 \%)$ \\
Male & \\
Anthropometric variables (mean \pm SD) & \\
Age (years) & $44.8 \pm 11.81$ \\
Weight $(\mathrm{kg})$ & $81.22 \pm 3.23$ \\
Height (m) & $1.65 \pm 0.02$ \\
BMI $\left(\mathrm{kg} / \mathrm{m}^{2}\right)$ & $29.8 \pm 2.45$ \\
Clinical data (n, \%) & \\
Diabetes mellitus & $17(100 \%)$ \\
SAH & $8(47 \%)$ \\
Smoking & $6(35.2 \%)$ \\
COPD & 0 \\
Asthma & 0 \\
Sedentary lifestyle & $12(70.5 \%)$ \\
Surgical data & \\
Duration of surgery (min) & $140 \pm 30$ \\
\hline
\end{tabular}

Note: kg: kilogram; m: meter; kg/m²: kilogram per square meter; SAH: systemic arterial hypertension; min: minute; COPD: chronic obstructive pulmonary disease.

The preoperative MIP was -100 [28-120], with no significant difference when compared to the predicted value $(-87.86$ [81.49-130.5]) $(\mathrm{p}=0.55)$ or the values obtained at PO1 (-120 [14-120]) and PO2 -120 [32-120]) $(\mathrm{p}=0.398)$ (Table 2).

Table 2 - Mean, median, minimum, maximum and standard deviation of MIP in the preoperative period, immediate postoperative period ( $\mathrm{PO}$ ) and late postoperative period ( $\mathrm{PO} 2$ ) and predicted value obtained for patients submitted to metabolic surgery

\begin{tabular}{lcccccc}
\hline MIP & Valid N & Mean & Median & Minimum & Maximum & $\begin{array}{c}\text { Standard } \\
\text { deviation }\end{array}$ \\
Preoperative & 15 & -99.26 & -100 & -28 & -120 & 26.74 \\
P01 & 14 & -99.57 & -120 & -14 & -120 & 33.89 \\
P02 & 17 & -105.41 & -120 & -32 & -120 & 29.28 \\
Predicted & 17 & -96.31 & -87.86 & -81.49 & -130.5 & 15.62 \\
\hline
\end{tabular}

Note: Data obtained by the authors. 
The preoperative MEP was 76 [60-120] and was significantly lower than the predicted value (87.54 [79.61140.19]) ( $\mathrm{p}=0.001)$. Analysis of MEP at PO1 showed a significant decrease (50 [28-108]) compared to the preoperative values $(\mathrm{p}=0.001)$. An increase in MEP was observed at PO2 (88 [40-120]), although the difference was not statistically significant when compared to preoperative values ( $\mathrm{p}=0.35$ ) (Table 3 ).

Table 3 - Mean, median, minimum, maximum and standard deviation of MEP in the preoperative period, immediate postoperative period (PO1) and late postoperative period (PO2) and predicted value obtained for patients submitted to metabolic surgery

\begin{tabular}{lcccccc}
\hline MEP & Valid N & Mean & Median & Minimum & Maximum & $\begin{array}{c}\text { Standard } \\
\text { deviation }\end{array}$ \\
Preoperative & 15 & 86.93 & $\star 76$ & 60 & 120 & 21.45 \\
P01 & 14 & 57.42 & $* 50$ & 28 & 108 & 24.03 \\
P02 & 17 & 92 & 88 & 40 & 120 & 26.26 \\
Predicted & 17 & 99.63 & 87.54 & 79.61 & 140.19 & 20.73 \\
\hline
\end{tabular}

Note: * Statistically significant. Source: Data obtained by the authors.

The preoperative BMI was 29.40 [24.24- 33.60]. Reassessmentaftertwoyears (PO2) revealed a significantly lower BMI (26.68 [20.47-33.40]), with the weight reduction being statistically significant $(\mathrm{p}=0.006)$ (Table 4$)$.

Table 4 - Mean, median, minimum, maximum and standard deviation of BMI in the preoperative period, immediate postoperative period (PO1) and late postoperative period (PO2) of patients submitted to metabolic surgery

\begin{tabular}{|c|c|c|c|c|c|c|}
\hline BMI & Valid N & Mean & Median & Minimum & Maximum & $\begin{array}{l}\text { Standard } \\
\text { deviation }\end{array}$ \\
\hline Preoperative & 14 & 29.72 & 29.40 & 24.24 & 33.60 & 2.48 \\
\hline PO1 & 14 & 28.95 & 28.99 & 23.44 & 32.43 & 2.59 \\
\hline PO2 & 14 & 26.95 & *26.68 & 20.47 & 33.40 & 3.53 \\
\hline
\end{tabular}

Note: * Statistically significant. Source: Data obtained by the authors.

A decrease in fasting glucose was observed from the preoperative period (228.40 [122.0-362.50]) to PO1 (157.05 [58.30-245.80]), but the difference was not significant $(\mathrm{p}=0.04)$. This reduction in fasting glucose at $\mathrm{PO} 1$ may have been caused by the hospitalization routine and diet to which the patients were submitted. An important and significant decrease $(\mathrm{p}=0.007)$ in fasting glucose was observed at PO2 (129.15 [79.10-268.50]) (Table 5).

Table 5 - Mean, median, minimum, maximum and standard deviation of fasting glucose in the preoperative period, immediate postoperative period (PO1) and late postoperative period (P02) of patients submitted to metabolic surgery

\begin{tabular}{|c|c|c|c|c|c|c|}
\hline Fasting glucose & Valid N & Mean & Median & Minimum & Maximum & Standard deviation \\
\hline Preoperative & 13 & 219.52 & 228.40 & 122.00 & 362.50 & 70.91 \\
\hline P01 & 16 & 151.28 & 157.05 & 58.30 & 245.80 & 51.54 \\
\hline P02 & 16 & 137.61 & *129.15 & 79.10 & 268.50 & 51.72 \\
\hline
\end{tabular}

Note: * Statistically significant. Source: Data obtained by the authors.

\section{Discussion}

Abdominal surgery can cause physiological alterations in the respiratory tract resulting from surgical trauma and the anesthetic procedure. Impaired inspiratory muscle strength causes a reduction in inspired pulmonary volume and this decreased volume, associated with impairment of the expiratory muscles, reduces expiratory flow and compromises the cough mechanism, favoring the retention of pulmonary secretions $[10,11]$. Factors such as pain, sedation and reduced ventilatory work induce hypoventilation and hypoxia, which have detrimental effects on the patient [12].

In addition to minimizing surgical risks, evaluation and preoperative care are important to prevent postoperative complications $[13,14]$. We did not find in the literature studies that evaluated MIP and MEP 
in the preoperative and immediate and late postoperative periods of metabolic surgery.

In the present study, the MEP was significantly reduced at P01 compared to the preoperative values. On the other hand, no statistically significant differences in MIP were observed between the pre- and postoperative periods of metabolic surgery. These results corroborate the findings of Kuhn etal. [15], who selected 10 patients, mainly females, submitted to abdominal surgery and measured respiratory pressures with a manovacuometer before and 48 hours after surgery. The authors observed a significant decrease in MEP ( $p=0.004)$ but not in MIP ( $p=0.678)$ [15]. Borges et al. [16] evaluated 40 female patients submitted to conventional laparoscopic and single portal laparoscopic cholecystectomy and observed a significant decrease in MIP and MEP 48 hours after the surgical procedure when compared to the preoperative period [16].

In our study, we also observed that both MIP and MEP were restored in the late postoperative period, with the mean and standard deviation being higher than those found in the preoperative period, but without statistical significance.

MIP, MEP, and transdiaphragmatic pressure decrease after high abdominal surgery. These decreases persist for at least 48 hours after surgery and may not return to normal until a week later. In particular, the reported incidence of respiratory muscle dysfunction is very low (2-5\%) after low abdominal surgery, but considerably higher (20-40\%) after high abdominal surgery, with the diaphragm being the most affected muscle [17]. In our study, no patient had respiratory complications during the postoperative period until discharge.

Smoking seems to be important in the genesis of postoperative pulmonary complications since it is associated with a decrease in secretion transport, an increase in mucus secretion, and airway narrowing [1821]. In our study, 6 (35.2\%) patients were smokers but their spirometric tests were normal before and after the surgical procedure.

The physiological disadvantages of prolonged anesthesia have been widely discussed and include, among others, arrhythmias, myocardial depression, hypotension, hypoxia, and pulmonary complications [22,23]. An association has been reported between a higher incidence of pulmonary complications in the postoperative period of abdominal surgery and the average duration of surgery exceeding 210 minutes [24]. In our study, the duration of the surgical procedure was $140 \pm 30 \mathrm{~min}$.
None of the patients developed complications during the postoperative period until hospital discharge.

A higher BMI can increase chest wall mass, which can result in pulmonary function deficiency [25]. In our study, the median BMI was $26.68 \mathrm{~kg} / \mathrm{m}^{2}$ in the late postoperative period of metabolic surgery, a value lower than the median preoperative BMI of $29.40 \mathrm{~kg} / \mathrm{m}^{2}$. This weight reduction was satisfactory and statistically significant $(\mathrm{p}=0.006)$.

Studies report that diabetes damages major organ systems through disrupted glycemic control and increased inflammation, including a reduction in lung volume and capacity [26-28]. With respect to structural changes in the respiratory muscles of diabetic patients, studies suggest that the occurrence of these alterations are associated with insulin resistance, nonenzymatic glycosylation of connective tissue, defective stimulation of pulmonary surfactant production, and the presence of a low-level chronic inflammatory state $[29,30]$. Physiotherapeutic evaluation during the preand postoperative periods of metabolic surgery is therefore important. In the present study, an important and significant reduction in fasting glucose was observed at PO2 ( $\mathrm{p}=0.007)$.

\section{Conclusion}

The present results showed a significant decrease of MEP in the immediate postoperative period/24 $\mathrm{h}$ after metabolic surgery, demonstrating a negative impact of this surgery on expiratory muscle strength. Significant weight loss and a significant reduction in fasting glucose were observed in the late postoperative period/2 years after surgery, with reestablishment of MIP and MEP. Further studies are needed to monitor patients in the pre- and postoperative period of metabolic surgery, identifying complications and acting on the care and functional recovery of these patients.

\section{Acknowledgement}

Financial support: Research Foundation of the State of Minas Gerais (FAPEMIG), National Council for Scientific and Technological Development (CNPq), Uberaba Teaching and Research Foundation (FUNEPU), and Coordination for the Improvement of Higher Education Personnel (CAPES). Study conducted at 
the Department of Surgery, Universidade Federal do Triângulo Mineiro (UFTM), Uberaba-MG, Brazil.

\section{References}

1. Hernanz-Rodriguez G, Pedrianes-Martin P, Pablos-Velasco P, Rodriguez-Perez A. Pancreatic beta cell function is preserved in the short term in patients with type 2 diabetes undergoing non-urgent surgery. Minerva Endocrinol. 2018;43(2):109-16.

2. Okur I, Taspinar B, Atalay OT,Pasali Kilit T, Toru Erbay U, Okur EO. The effects of type 2 diabetes mellitus and its complications on physical and pulmonary functions: A case-control study. Physiother Theory Pract. 2018:1-7.

3. Elrayah-Eliadarous H, Östensson CG, Eltom M, Johansson P, Sparring V, Wahlström R. Economic and social impact of diabetes mellitus in a low-income country: A casecontrol study in Sudan. J Diabetes. 2017;9(12):1082-90.

4. Lee WJ, Aung L. Metabolic surgery for type 2 diabetes mellitus: experience from Asia. Diabetes Metab J. 2016;40(6):433-43.

5. Chen W, Xu Q, Xiao Y, Zhou J, Zhang W, Lin G, Gong F. Blockade of central GLP-1 receptors deteriorates the improvement of diabetes after ileal transposition. Int J Med Sci. 2016;13(12):955-62.

6. Menezes TC, Bassi D, Cavalcanti RC, Barros JESL, Granja KSB, Calles ACDN, et al. Comparisons and correlations of pain intensity and respiratory and peripheral muscle strength in the pre- and postoperative periods of cardiac surgery. Rev Bras Ter Intensiva. 2018;30(4):479-86.

7. Pereira CAC, Neder JA. Diretrizes para testes de função pulmonar. J Bras Pneumol. 2002;28(Supl 3):1- 238.

8. Neder JA, Andreoni S, Castelo-Filho A, Nery LE. Reference values for lung function tests. I. Static volumes. Braz J Med Biol Res. 1999;32(6):703-17.

9. Kurisu $\mathrm{S}$, Nitta $\mathrm{K}$, Sumimoto $\mathrm{Y}$, Ikenaga $\mathrm{H}$, Ishibashi $\mathrm{K}$, Fukuda Y, et al. Frontal QRS-T angle and World Health Organization classification for body mass index. Int J Cardiol. 2018;272:185-8.

10. Leiner GC, Abramowitz S, Small MJ, Stenby VB, Lewis WA. Expiratory peak flow rate. Standard values for normal subjects. Use as a clinical test of ventilatory function. Am Rev Respir Dis. 1963;88:644-51.
11. Oliveira MA, Vidotto MC, Nascimento OA, Almeida R, Santoro IL, Sperandio EF, et al. Evaluation of lung volumes, vital capacity and respiratory muscle strength after cervical, thoracic and lumbar spinal surgery. Sao Paulo Med J. 2015;133(5):388-93.

12. Lunardi AC, Paisani Dde M, Tanaka C, Carvalho CR. Impact of laparoscopic surgery on thoracoabdominal mechanics and inspiratory muscular activity. Respir Physiol Neurobiol. 2013;186(1):40-4.

13. Agrelli TF, Borges MC, Cunha FMR, Silva EMC, Terra Jr JA, Crema E. Combination of preoperative pulmonary and nutritional preparation for esophagectomy. Acta Cir Bras. 2018; 33(1):67-74.

14. Patman S. Critically appraised paper: Preoperative physiotherapy education halved postoperative pulmonary complications in patients after upper abdominal surgery [commentary]. J Physiother. 2018;64(3):195.

15. Kuhn B, Encarnação BH, Costa C, Hansen D, Laux KC, Moussalle LD. Avaliação da força muscular respiratória e da função pulmonar de pacientes submetidos à cirurgia abdominal. Educación Física y Deportes (EFDeportes. com). Revista Digital. 2016;21(220).

16. Borges MC, Takeuti TD, Terra JrJA, Silva AA, Crema E.Comparative study of respiratory muscle strength in women undergoing conventional and single-port laparoscopic cholecystectomy. Acta Cir Bras. 2017;32(10):881-90.

17. LoMauro A. Should the diaphragm be evaluated after abdominoplasty? J Bras Pneumol. 2019;45(3):e20190146.

18. Matsuoka K, Yamada T, Matsuoka T, Nagai S, Ueda M, Miyamoto Y. Preoperative smoking cessation period is not related to postoperative respiratory complications in patients undergoing lung cancer surgery. Ann Thorac Cardiovasc Surg. 2019;25(6):304-10.

19. Quan H, Ouyang L, Zhou H, Ouyang Y, Xiao H. The effect of preoperative smoking cessation and smoking dose on postoperative complications following radical gastrectomy for gastric cancer: a retrospective study of 2469 patients. World J Surg Oncol. 2019;17(1):61.

20. Bayfield NGR, Pannekoek A, Tian DH. Preoperative cigarette smoking and short-term morbidity and mortality after cardiac surgery: a meta-analysis. Heart Asia. 2018; 10(2):e011069. 
21. Yoshida N, Nakamura K, Kuroda D, Baba Y, Miyamoto $\mathrm{Y}$, Iwatsuki $\mathrm{M}$, et al. Preoperative smoking cessation is integral to the prevention of postoperative morbidities in minimally invasive esophagectomy. World J Surg. 2018;42(9):2902-9.

22. Ellis TA, Bracho DO, Krishnan S. Responding to a Respiratory Complication in the Recovery Room: A Simulation Case for Anesthesiology Students. MedEdPORTAL. 2017; 13:10529.

23. Seelhammer TG, DeGraff EM, Behrens TJ, Robinson JC, Selleck KL, Schroeder DR, et al. The use of flumazenil for benzodiazepine associated respiratory depression in postanesthesia recovery: risks and outcomes. Rev Bras Anestesiol. 2018;68(4):329-35.

24. Pereira EDB, Faresin SM, Juliano Y, Fernandes ALG. Risk factors of postoperative pulmonary complications after upper abdominal surgery. J Pneumol. 1996;22:19-26.

25. Lecube A, Sampol G, Muñoz X, Hernández C, Mesa J, Simó R. Type 2 diabetes impairs pulmonary function in morbidly obese women: a case-control study. Diabetologia. 2010;53(6):1210-6.
26. Sonoda N, Morimoto A, Tatsumi Y, Asayama K, Ohkubo T, Izawa $\mathrm{S}$, et al. A prospective study of the impact of diabetes mellitus on restrictive and obstructive lung function impairment: The Saku study. Metabolism. 2018;82:58-64.

27. Shah SH, Sonawane P, Nahar P, Vaidya S, Salvi S. Pulmonary function tests in type 2 diabetes mellitus and their association with glycemic control and duration of the disease. Lung India. 2013;30(2):108-12.

28. Ramirez LC, Dal Nogare A, Hsia C, Arauz C, Butt I, Strowig $\mathrm{SM}$, et al. Relationship between diabetes control and pulmonary function in insulin-dependent diabetes mellitus. Am J Med. 1991;91(4):371-6.

29. Fernández-Real JM, Chico B, Shiratori M, Nara Y, Takahashi H, Ricart W. Circulating surfactant protein A (SPA), a marker of lung injury, is associated with insulin resistance. Diabetes Care. 2008;31(35):958-63.

30. Sin DD, Man SF. Why are patients with chronic obstructive pulmonary disease at increased risk of cardiovascular diseases? The potential role of systemic inflammation in chronic obstructive pulmonary disease. Circulation. 2003;107(11):1514-9.

Received: 07/05/2019

Recebido: 05/07/2019

Approved: 02/03/2020

Aprovado: 03/02/2020 